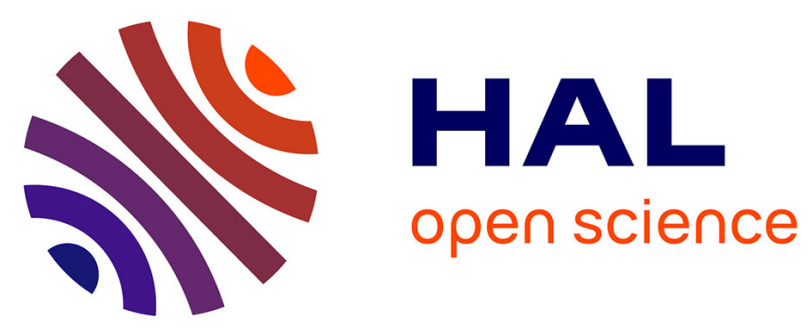

\title{
Solar Orbiter/Radio and Plasma Wave observations during the first Venus flyby
}

Niklas J T Edberg, Lina Hadid, Milan Maksimovic, Stuart D Bale, Thomas

Chust, Yuri Khotyaintsev, Volodya Krasnoselskikh, Matthieu Kretzschmar, Eric Lorfèvre, Dirk Plettemeier, et al.

\section{To cite this version:}

Niklas J T Edberg, Lina Hadid, Milan Maksimovic, Stuart D Bale, Thomas Chust, et al.. Solar Orbiter/Radio and Plasma Wave observations during the first Venus flyby. EGU General Assembly 2021, Apr 2021, online, France. 10.5194/egusphere-egu21-12198 . hal-03215601

\section{HAL Id: hal-03215601 https://hal.sorbonne-universite.fr/hal-03215601}

Submitted on 3 May 2021

HAL is a multi-disciplinary open access archive for the deposit and dissemination of scientific research documents, whether they are published or not. The documents may come from teaching and research institutions in France or abroad, or from public or private research centers.
L'archive ouverte pluridisciplinaire HAL, est destinée au dépôt et à la diffusion de documents scientifiques de niveau recherche, publiés ou non, émanant des établissements d'enseignement et de recherche français ou étrangers, des laboratoires publics ou privés. 
EGU21-12198, updated on 03 May 2021

https://doi.org/10.5194/egusphere-egu21-12198

EGU General Assembly 2021

(c) Author(s) 2021. This work is distributed under

the Creative Commons Attribution 4.0 License.

\section{Solar Orbiter/Radio and Plasma Wave observations during the first Venus flyby}

Niklas J. T. Edberg ${ }^{1}$, Lina Hadid ${ }^{2}$, Milan Maksimovic ${ }^{3}$, Stuart D. Bale ${ }^{4,5}$, Thomas Chust ${ }^{2}$, Yuri Khotyaintsev ${ }^{1}$, Volodya Krasnoselskikh ${ }^{6}$, Matthieu Kretzschmar ${ }^{6,7}$, Eric Lorfèvre ${ }^{8}$, Dirk Plettemeier ${ }^{9}$, Jan Souček ${ }^{10}$, Manfred Steller ${ }^{11}$, Štěpán Štverák ${ }^{12}$, Pavel Trávníček ${ }^{4,12}$, Andris Vaivads $^{13}$, Antonio Vecchio $^{14}$, Tim Horbury ${ }^{15}$, and the RPW team \& MAG team ${ }^{*}$

${ }^{1}$ Swedish Institute of Space Physics - Uppsala, Frösön, Sweden (ne@irfu.se)

${ }^{2}$ LPP, CNRS, Ecole Polytechnique, Sorbonne Université, Observatoire de Paris, Université Paris-Saclay, PSL Research University, Palaiseau, Paris, France

${ }^{3}$ LESIA, Observatoire de Paris, Université PSL, CNRS, Sorbonne Université, Univ. Paris Diderot, Sorbonne Paris Cité, 5 place Jules Janssen, 92195 Meudon, France

${ }^{4}$ Space Sciences Laboratory, University of California, Berkeley, CA, USA

${ }^{5}$ Physics Department, University of California, Berkeley, CA, USA

${ }^{6} \mathrm{LPC2E}, \mathrm{CNRS}, 3 \mathrm{~A}$ avenue de la Recherche Scientifique, Orléans, France

${ }^{7}$ Université d'Orléans, Orléans, France

${ }^{8} \mathrm{CNES}, 18$ Avenue Edouard Belin, 31400 Toulouse, France

${ }^{9}$ Technische Universität Dresden, Würzburger Str. 35, D-01187 Dresden, Germany

${ }^{10}$ Institute of Atmospheric Physics of the Czech Academy of Sciences, Prague, Czechia

${ }^{11}$ Space Research Institute, Austrian Academy of Sciences, Graz, Austria

${ }^{12}$ Astronomical Institute of the Czech Academy of Sciences, Prague, Czechia

${ }^{13}$ Department of Space and Plasma Physics, School of Electrical Engineering and Computer Science, Royal Institute of Technology, Stockholm, Sweden

${ }^{14}$ Research Institute for Mathematics, Astrophysics and Particle Physics Radboud University, Nijmegen, The Netherlands

${ }^{15}$ Department of Physics, Imperial College London, London SW7 2AZ, UK

${ }^{*}$ A full list of authors appears at the end of the abstract

We present measurements from the Radio and Plasma Wave (RPW) instrument suite onboard the Solar Orbiter mission during the first Venus encounter. RPW consists of several units and is capable of measuring both the electric and magnetic field fluctuations with three electric antennas and a search-coil magnetometer: The Low Frequency Receiver (LFR) cover the range from DC up to $10 \mathrm{kHz}$ when measuring the electric and magnetic waveform and spectra; the Thermal Noise and High Frequency Receiver (TNR-HFR) determines the electric power spectra and magnetic power spectra from $4 \mathrm{kHz}-20 \mathrm{MHz}$, and $4 \mathrm{kHz}$ to $500 \mathrm{kHz}$, respectively, to determine properties of the electron population; the Time Domain Sampler (TDS) measures and digitizes onboard the electric and magnetic field waveforms from $100 \mathrm{~Hz}$ to $250 \mathrm{kHz}$. The BIAS subunit measures DC and LF electric fields as well as the spacecraft potential, which gives a high cadence measure of the local plasma density when calibrated to the low-cadence tracking of the plasma peak from the TNR. Solar Orbiter approached Venus from the induced magnetotail and had its closest approach at an 
altitude of $7500 \mathrm{~km}$ over the north pole of Venus on 27 Dec 2020. The RPW instruments observed a tail region that extended several 10's of Venus radii downstream of the planet. The induced magnetosphere was characterized to be a highly dynamic environment as Solar Orbiter traversed the downstream tail and magnetosheath before it crossed the Bow Shock outbound at 12:40 UT. Polarized whistler waves, high frequency electrostatic waves, narrow-banded emissions, possible electron double layers were observed. The fine structure of the bow shock could also be investigated in detail. Solar Orbiter could hence enhance the knowledge of the structure of the solar wind-Venus interaction.

RPW team \& MAG team: RPW team: A. Dimmock, A. I. Eriksson, D. Graham, K. Steinvall, E. Yordanova, Luca Sorriso-Valvo, A. Retino, O. Le Contel MAG team: Helen O'Brien, Vincent Evans and Virginia Angelini 